\title{
Social Classes in the Process of Capitalist Landnahme On the Relevance of Secondary Exploitation
}

KLAUS DÖRRE

Labour Studies and Economic Sociology, Friedrich-Schiller-University of Jena, Germany

\begin{abstract}
So far, growing social insecurity and inequality have not led to a revival of classconscious labour movements in the centres of capitalism. This article builds upon Rosa Luxemburg's concept of Landnahme to attempt to explain this phenomenon. In contemporary Germany, as in other developed countries, a transition from a society pacified by Fordist methods to a more strongly polarized class society is taking placethough characterized by a peculiar 'stabilization of the unstable'. An 'interior' Landnahme set in motion by financial capitalism has also severely aggravated secondary exploitation and the precarization of labour. Trade unions and the segment of the working class represented by unions often react by closing their ranks in exclusive solidarity. Faced with the prospect of downward social mobility, they develop defensive strategies to preserve their remaining social property - even at the expense of precarized groups. Such a disciplinary régime can only be broken if precarized groups and their forms of working and living are integrated into new structures of inclusive solidarity.
\end{abstract}

\section{Résumé}

Jusqu'ici, l'insécurité et l'inégalité croissante n'ont pas abouti à une renaissance des mouvements ouvriers dotés d'une conscience de classe au cœur du capitalisme. Cet article cherche à expliquer ce phénomène à partir du concept de Landnahme de Rosa Luxemburg. Dans l'Allemagne d'aujourd'hui, comme dans d'autres pays développés, une transition d'une société apaisée par des méthodes Fordistes à une société fortement polarisée est en train de se réaliser - bien que caractérisée par une étrange 'stabilisation de l'instable'. Un Landnahme 'intérieur' mu par le capitalisme financier a

\footnotetext{
Dr Klaus Dörre is full professor of Labour Studies and Economic Sociology at the Friedrich-Schiller-University of Jena. Also, since 2010 he is director of the local institute of sociology. Furthermore, he is a member of the Council of the German Sociological Association (Deutsche Gesellschaft für Soziologie). His research interests include theories of capitalism/finance capitalism, flexible and precarious employment, employee participation, industrial relations and Green New Deal. Currently, he is working on a monograph about the concept of capitalist 'Landnahme'.

Dr Klaus Dörre est professeur d'Etudes Ouvrières et de Sociologie Economique à l'Université Friedrich Schiller de Jena. Depuis 2010, il est également directeur de l'institut de sociologie local. En outre, il est membre du Conseil de l'Association sociologique d'Allemagne (Deutsche Gesellschaft für Soziologie). Parmi ses intérêts dans le domaine de la recherche sont les théories du capitalisme/le capitalisme financier, le travail précaire, la concertation salariale, les relations industrielles et le 'New Deal' Vert. Il est actuellement en train d'élaborer une monographie sur le concept du 'Landnahme' capitaliste.
}

Socialist Studies: the Journal of the Society for Socialist Studies/ Études socialistes: Revue de la Société d'études socialistes www.socialiststudies.com 
Socialist Studies / Études socialistes 6(2) Fall 2010: 43-74

\begin{abstract}
également gravement renforcé l'exploitation secondaire et la précarisation de la classe ouvrière. Les syndicats et les fragments de la classe ouvrière que les syndicats représentent réagissent souvent en fermant leurs rangs dans une solidarité exclusive. Craignant la mobilité sociale descendante, ils développent des stratégies défensives afin de préserver la propriété sociale qui leur reste - même au dépens des groupes précarisés. Un tel régime disciplinaire peut seulement être brisé si les groupes précarisés et leurs formes de travail et modes de vie sont intégrés dans des nouvelles structures de solidarité inclusive.

\section{Keywords}

financial capitalism • Landnahme • precarization • reserve army mechanism • secondary exploitation $\bullet$ social classes

Mots-clés

capitalisme financier • Landnahme • précarisation • mécanisme de l'armée de réserve - exploitation secondaire • classes sociales
\end{abstract}

At the beginning of the 21st century, the Social Question is once again at the centre of politics in the developed capitalisms. The return of social insecurity to wealthy Western countries, including Germany ${ }^{1}$, has sparked a renaissance of class theories (Thien 2009, 7-22). Yet this analysis is faced with a dilemma. With neoliberalism began 'the momentous shift towards greater social inequality and the restoration of economic power (of) the upper classes.' (Harvey 2005, 26) And yet, the successful bottom-top redistribution this project brought about has not, so far, generated political class awareness among those ruled by that system. As a result of the global economic crisis in 2008/09, the political Left and unions are struggling to get back on their legs in most European countries (Hyman/GumbrellMcCormick 2010; Milkman 2010). How can this be explained?

To attempt to answer this question, this article begins with Rosa Luxemburg's concept of 'Landnahme'. Germany, like other developed states, is currently experiencing a transition from a society pacified by Fordist methods to a more strongly polarized class society. This transition is characterised by a kind of stabilization of the unstable. An 'inner' Landnahme from the ranks of financial capitalism has made the principle of competitiveness the major principle for social organization, becoming a catalyst for class conditions based significantly on secondary exploitation, accompanied by precarization, forcing subordinate groups with

\footnotetext{
${ }^{1}$ Since the mid-1980s, in (West) Germany, a discourse on individualization and pluralization of social inequality had displaced approaches of class theory to a great extent (cf. Beck 1983).
} 
unfashionable forms of organization and political intervention to give up hard-won social welfare protection measures. Building upon Rosa Luxemburg's concept of Landnahme ${ }^{2}$, this article extends the concept of exploitation and illustrates its relevance through analysis of contemporary developments in Germany's coordinated capitalism.

\section{Landnahme, Classes and (Secondary) Exploitation}

Karl Marx was the first to provide an analysis of capitalist expansion as Landnahme. In his treatment of 'so-called primitive accumulation' (Marx 1867, Part VIII), he outlines the formation of capitalism in a non-capitalist environment. In Marx's view, the development of capitalist conditions of class and property historically precede capitalist methods of production. The expropriation of the peasantry is the central prerequisite for the genesis of doubly free labourers who are neither bound to the land nor to any guilds. Marx described this process, which ultimately leads to a monopolization of privately owned means of production among a small group of owners, as an extremely brutal procedure of peasant expropriation, compulsory dispossession of common land and expropriation of Church estates amidst colonial oppression and slave trading. Since he was mainly observing British developments, Marx polemically overpaints the brutality of this transition process (Thompson 1987, 203pp.). Nonetheless, his insights are still relevant as a heuristic device guiding research on class theory.

Following Marx, it may be argued that Landnahme means (1) expansion of capitalist production methods internally and externally. Large-scale industry provided a permanent basis for capitalist agriculture; it completed the separation of farming and rural domestic trades and 'conquers for industrial capital the entire home market.' (Marx 1867, 738.). This process took several centuries and conditions of capitalist production began to prevail generally only in the course of the industrial revolution; the parallel existence of capitalist alongside non-capitalist class conditions is characteristic of capitalism, not exceptional. The traditional and new conditions are not strictly separate. Rather, the everyday lives of individuals and social groups are characterized by a great variety of syntheses of new and old forms (Braudel 1985, 1986). Thus the doubly free labourer as stylized by Marx is an abstraction. Even after the onset of the industrial revolution, over a long period of time, the greater part of the

\footnotetext{
${ }^{2}$ Rosa Luxemburg herself writes of 'colonization'; she did not actually use the term Landnahme.
} 
industrial proletariat remained embedded in traditional, rural conditions of life and production (Lutz 1984).

The changes to ownership conditions and the expropriation of the peasantry and the conditioning and disciplining of 'free' labour for the new production methods required state support. Thus Landnahmen are (2) always politically controlled processes, as well. Notably, during capitalism's early phase, laws dating back to feudal times were used to generally establish compulsory labour and to politically regulate wages (Marx 1867, 723pp.). Even later, during the industrial revolution, conditions were based on workers' political exclusion. By playing midwife to capitalist production methods, a repressive bourgeois state contributed to the formation of markets in a context of structural power asymmetries: these were partly politically initiated and therefore never an exclusively economic matter. The 'free' population was mobilized and disciplined for the capitalist way of production, to a significant degree, by political coercive mechanisms mobilized by the state. For Marx, the intensive use of political coercion includes physical force; in its extensive form, political coercion is part of capitalism's early history. Marx predicted the emergence of a proletariat which 'by upbringing, tradition, custom recognizes the standards of that form of production as undeniable natural laws'. Extraeconomic force is thus only used in exceptional situations. In general, workers can be kept under control by means of the 'natural laws of production' (Marx 1867, 727).

Yet if we think of capitalist development as a sequence of different formations, production methods and class conditions, then the universal validity of Marx's premises is questionable. Following Rosa Luxemburg, we maintain that capitalist development (3) is always based on two mutually dependent processes. The first dominates the places of production of surplus value, i.e. factories, fully capitalized agriculture and commodity markets. Here, to a great extent, capitalism reproduces itself on its own foundations; the principle of equivalent exchange applies. As a result of social struggles, wage-dependent labourers are paid approximately according to the value of their labour. However, Luxemburg argues that in such 'interior dealings' only a limited part society's overall product value can be realized. The second process thus finds its way into exchange relationships, between capital accumulation on the one hand and noncapitalistic production methods, social actors and territories on the other (Luxemburg 1975, 315). With an absolute as well as relative increase of labour value in relation to the surplus value created, in internal capitalist markets, the problem of achieving profit constantly becomes more acute 
(ibid., 316). This forces expanding enterprises to commercialize parts of the surplus value 'externally', outside of capitalist production methods, capitalist social relationships and given political territories.

In this context, 'external' does not necessarily mean outside national boundaries. There is a merging of interior capitalist markets beyond the borders of nation-states, as Luxemburg observes. At the same time, within national societies, there are regions, milieus, groups and activities that are not commodified or only partly commodified, where different forms of exchange are dominant in contrast to capitalist markets. In the 'outer markets', the principle of equivalent exchange, of exchanging values of similar magnitude, applies to a limited degree at best; arbitrariness and even open violence are predominant here $(2005,137)$. Such violence aims to at least temporarily maintain social groups, territories or even entire countries at a pre-capitalist or less developed stage. In this 'external' sphere, as David Harvey $(2005,147)$ points out, capitalism sometimes shows characteristics of 'fraudulence' and 'predatoriness'. Such dialectical 'interior-exterior' mechanisms provide the dominant capitalist players (companies, owners, managers) with the possibility of factoring noncapitalist territories, ways of production and social strata into their accumulation strategies. As a consequence, they are no transient phenomenon, but a constant concomitant of capitalist development.

Following this, Landnahmen are based (4) on contingent processes which in the long run aim to reposition and at least temporarily overcome the limits of capitalist accumulation established by 'outer' markets and, ultimately, by human and extra-human nature. Yet, generating value in 'exterior' markets is not a linear process. Instead, the dialectics of interior and exterior constantly provide the opportunity for regressive modernization. Particularly in times of stagnating accumulation, capitalist players as 'first movers' tend to ignore rules and practice over-exploitation to achieve extra profits. Luxemburg's analysis thus interprets the problem of capitalist development as a structural imperative to grow. ${ }^{3}$ The individual capitalist can only prevent his or her own decline by permanently improving the means of production and expanding output. Therefore, overall production constantly tends to surpass solvent demand, and due to productivity increases, the volume of material products tends to

3 'Capitalist methods of production do more than awaken in the capitalist this thirst for surplus value whereby he is impelled to ceaseless expansion of reproduction. Expansion becomes in truth a coercive law, an economic condition of existence for the individual capitalist.' (Luxemburg 1913, 12). 
exceed the increase in (surplus) value already realized. Meanwhile, an expansive finance sector provides funding for entrepreneurial risks in expectation of future profits, creating pressures to innovate. In this system, crisis-related setbacks in growth bring about unemployment and precarization.

According to Luxemburg, the pressure for extended reproduction inherent in capitalism is accompanied by a multi-faceted problem of profit realization that is by no means limited to a simple underconsumption theory. Periodically, every single capitalist needs to find exactly those material means of production, manpower and sales markets appropriate to his or her stage in the accumulation process (Luxemburg 1975, 24). In an anarchic economic framework where this correspondence can only be brought about by millions of individual microeconomic operations, the reproduction of capital must remain fragile. The metamorphosis of surplus value into money, of money into productive capital, i.e. into specific goods, and the transformation of goods fed into the production process into (surplus) value and money remains crisis-prone in each of its stages. Under-consumption is only one specific instance of crisis within a chain in which every link is potentially crisis-ridden. From the perspective of the present day, over-accumulation or the extensive exploitation of exhaustible natural resources, without taking into account actual needs, is the most potentially devastating link in the capitalist production process.

In sum, in the process of extended reproduction, individual capitalists are unable to create an extended sales market by themselves; for better or for worse, they are dependent on society to create the extended markets needed to resolve the many-faceted, complex problem of realizing profit. As individuals, they are 'powerless' against this realization problem. This creates structural pressure for growth, a dynamic that explains the 'contradictory phenomenon' that 'the old capitalist countries provide ever larger markets for, and become increasingly dependent upon, one another, yet, on the other hand compete ever more ruthlessly for trade relations with non-capitalist countries' (Luxemburg 1913, 347).

The implications of the breakdown theory in Luxemburg's Landnahme concept have been criticized frequently. Harvey (2003, 138pp.) correctly points out that Rosa Luxemburg underestimates the potential for a politics of reinvestment to create demand for capital goods and revolutionize the means of production. Additionally, in the long run, geographic expansion can stimulate capitalism. Rather then maintaining peripheral countries in a permanent state of non-development, they may be used as stable spheres of investment. In this respect, the interior- 
exterior dialectics of capitalist development do not include automatic collapse. Yet Lutz (1984) and Harvey (2004) offer an alternative interpretation of Landnahme theory: capitalist players (5) may counter structural problems of development through passive revolutions. Accumulation regimes and ownership conditions, ways of regulation and production models are circulated and transformed, although always with the aim of preserving the capitalist system (Gramsci 1991, 101p.; 1999, 2063pp.). Such transformations are possible because within concrete space-time relations, capitalism can always refer to an 'outside' which it creates itself to some extent: 'capitalism can either make use of some preexisting outside (non-capitalist formations or some sector within capitalism - such as education - that has not yet been proletarianized) or it can actively manufacture it.' (Harvey 2003, 141). Active generation of a non-capitalist other is a reaction to difficulties realizing profits and is part of broader strategies to counter the tendency towards over-accumulation (lack of investment opportunities) by 'shifting' capital in space and/or time. Capitalist development can therefore be seen as a permanent search for new ways of fixing capital in space-time. Such fixing of capital in spacetime not only ties invested capital to 'locations' which promise monopoly profits due to unique qualities; insofar as these ties are long-term, they temporarily defuse the over-accumulation problem and thus temporarily 'repair' capitalism (Harvey 2003, 115).

The active generation of an outside' therefore means (6) that in principle, the chain of acts of Landnahme is endless. 'Falling from grace' by 'going beyond the scope of purely economic regulations by means of political actions' (Arendt 2006, 335, translated from the German edition) is a continuously necessary process, like a constantly-extended stepladder. Capitalist dynamics depend, fundamentally, on the ability to produce and to destroy space in time. By investing in machinery, factories, labour and infrastructure, capital establishes spatial ties it cannot sever without cost and attrition. In this, investments intended to economically develop spaces - e.g. funding for traffic infrastructure, access to raw materials or investments in education and training, occupational health and safety have a particular function. Such investments can only be redeemed over long periods of time, i.e. they are temporarily removed from the primary capital cycle (immediate consumption) and redirected to the secondary cycle (capital for revolutionizing the means of production, the creation of funds for consumption, e.g. housing) or the tertiary cycle (investment in research, development, social matters). Yet there is no guarantee that such investments will be profitable. Hence the state takes on the function of the 
'collective ideal capitalist' when long-term investments are required, so creating an 'outside' for individual molecular capitalist operations, a sphere which is partly inaccessible to private accumulation, but which can be used to improve economic performance and privatized at a later point in time. Insofar as temporary forms of market socialization become obstacles to capital realization, mobile capital seeks to ease or eliminate capital previously fixed in space-time. Where the elimination of such fixed capital leads to de-industrialization, economic decline, mass unemployment and poverty, yet another 'outside' is created - devastated, abandoned regions and an unused workforce that in a later phase of development may become suitable as the objects and potential assets of new investment strategies. This dialectical process of Landnahme suggests that the parallel existence of qualitatively different class conditions and class relations in space-time, both within and outside national societies, is an element of normally-functioning capitalism.

Dominant capitalist players (owners, managers, companies, etc.) may use such simultaneity of the unsimultaneous to (7) preserve and institutionalize secondary exploitation. 'Secondary' does not mean less painful, less brutal or less significant. Rather, the rationality of equivalent exchange which structures primary capitalist exploitation does not apply, or only to a limited extent. Classic examples of secondary exploitation are the functionalization of reproductive work by women or the establishment of a transitory status for migrants. In the first case, symbolic-habitual and political mechanisms hierarchize occupations by means of gender-specific constructs. The devaluation of reproductive work and relative exclusion of socially sheltered full-time employment have an historic origin (Aulenbacher 2009, 65-80). In the second case, the transitory status of migrants based on relative disfranchisement and dislocation perpetuates a specific difference between inside and outside whose intended effect is to ensure a supply of cheap labour that can be mobilized for unattractive segments of the labour market where work requires little qualification, is burdensome and badly paid. Secondary exploitation exists whenever symbolic forms of pressure and pressure applied politically by the state are utilized to preserve differences between 'inside' and 'outside' with the aim of pushing the price of labour for certain social groups below its actual value or of excluding these groups from the capitalist relationship of exploitation. Secondary exploitation therefore manifests a tension-filled synthesis of universalism and particularism characteristic of any capitalist Landnahme. The universalistic claim of capital realization is functionally dependent on particularistic regulations such as the national state; yet the 
global economic system can only exist within a network of power relations withinn as well as between states, which constantly reproduces differences between 'inside' and 'outside'.

This analysis makes it (8) possible to more precisely define the significance of class conditions, marginalization and precarization for capitalism's economic rationalism. Marx's 'reserve army' of labour mechanism, analysed in the first volume of 'Capital', is one way of actively generating an 'outside' to counteract the state's de-commodification measures. In its various guises, the industrial reserve army of labour can be used during economic booms to mobilize additional labour under conditions advantageous to capital. At the same time, those excluded from capitalist production represent latent pressure that may be used to reduce labour costs and provide incentives for investment. Above all, though, 'workers are simply ejected from the system at a certain point' to ensure 'that they are available at a later point for purposes of accumulation'. Thus, capitalism creates 'something outside of itself' (Harvey 2003, 140). The social question always includes an 'inside' and an 'outside': the 'inside' represents the core activity of exploitation, the private appropriation of collectively generated surplus value, while the 'outside' refers to reduced income, living conditions below accepted class standards, over-exploitation and in extreme cases, complete exclusion from employment.

\section{Fordist Landnahme and Class Relations}

Marx hoped such divisions would be overcome during political class formation. Although he described the Reserve Army of Industry as a large, socially highly differentiated group, he did consider it a potential element of the working class. But, to overcome divisions and competition would require 'regular co-operation between employed and unemployed' (Marx $1867,634)$ through a unified, class-conscious political body or trade union.

\section{The Reserve Army mechanism ...}

Since Marx observed an industrial proletariat whose living conditions were structurally precarious (ibid., 670; Mooser 1984; Paugam 2008, 48-50), such an interpretation appears reasonable. Yet his logic is inconsistent. An extremely heterogeneous Reserve Army which is 'fluid', 'latent', 'stagnant' and highly pauperized (Marx 1867, 634pp), functions both as the potential subject of class solidarity whilst also acting as a disciplining force, 'put(ting) pressure on the active army of workers during periods of stagnation and medium prosperity and during the period of overproduction and paroxysm keep(ing) its demands in check' (ibid.). It is 
Socialist Studies / Études socialistes 6(2) Fall 2010: 43-74

unclear why these precarized groups partly integrated in non-capitalist milieus would ally with the active part of the proletariat. Rosa Luxemburg $(1913,343)$ saw this problem clearly. In her view, 'the emancipation of labour power from primitive social conditions and its absorption by the capitalist wage system is one of the indispensable historical bases of capitalism.' She continues: 'Yet, as we have seen, capitalism in its full maturity also depends in all respects on non-capitalist strata.' (ibid., 345). Even if we reject Luxemburg's model of static reproduction, we can accept her central observation that non-capitalist forms of production and different social strata co-exist with capitalism. The following analysis draws on this insight to explain the Reserve Army mechanism, its temporary disappearance and its re-emergence in the course of the latest Landnahme of financial capitalism.

... its temporary disappearance... According to Burkardt Lutz (1984), the weak growth of capitalism after World War I resulted mainly from capitalists' inability to break up the dualism of modern industry and the traditional sector, which limited solvent demand. For a long time, exchange relations between modern industry and a sector with agrarian and small-scale business structures, pre-modern life styles and value orientations ensured that labour costs did not rise above certain limits. The traditional sector provided a workforce potential industry could access to satisfy its needs and then, in times of crisis, return as 'surplus' labour to this 'outside' sector. In addition, wages circulated at a margin defined to a significant extent by the consumption of goods in the traditional sector. It was possible to limit the reproduction costs of labour as a commodity because workers procured most of their essential goods from the traditional sector, characterized by small trade and agrarian production and thus providing more or less inexpensive products.

What made it possible for capitalist players in the central countries of Western Europe to crack the so-called 'Lohngesetz'4 were the basic political conditions: state interventionism, the 'New Deal' model with mass production, mass consumption and individualistic life styles, along with an elite consensus to allow wage earners' to participate in economic growth.

\footnotetext{
${ }^{4}$ By 'Lohngesetz' (Germ.: 'wage law'), Lutz $(1984,210)$ means 'that wages in the modern sector of the national economy can rise neither significantly nor permanently above the supply level present among the poorer parts of the traditional sector, which is primarily defined by barter economy.'
} 
DÖRRE: Social Classes in the Process of Capitalist Landnahme

During a period in which the traditional sector was irreversibly absorbed, the 'wage law' was neutralized. Wherever the traditional sector's functions could not be delegated to industry and the capitalist market, they were taken on by the state and an expanding public sector. As a result, real wages rose significantly within twenty years (1950-1970), a development brought about in Germany as a result of only a few large, exemplary social conflicts. Both quantitatively and qualitatively, this meant a unique rise in the living standards of wage earners and their families ${ }^{5}$. Wage labour was linked with strong social rights of protection and participation. The generalization of wage labour in society, i.e. the displacement of labour for the capitalist labour market (commodification) was possible because an expanding welfare state ensured that wage labour was uncoupled from market risks to a great extent (de-commodification).

What developed was a 'Gesellschaft der Ähnlichen' ('Society of the Similar'; Castel 2005, 46), enabling large portions of the working class to attain the lifestyles and security that middle levels of society enjoyed, despite persistent inequality and hierarchies. A major element of this ascent was access to social property intended to ensure that basic needs were met. Typically, this included pensions and health insurance benefits, as well as the acceptance of collective bargaining standards and some codetermination rights at work and in society. In this Society of the Similar, major differences between classes and class factions had not disappeared, but the claim to social property changed the lives of wage labourers and their families, making it possible to plan to a certain extent (Sennett 2007, 24). Large and smaller businesses with stable internal labour markets as well as a well-developed public sector ensured that in a mixed economy, the collective safety net for wage labour enabled individuals to have 'careers'.

For the first time in history, even if only for a short period, within the coordinated capitalism of the German type, a capitalism without a visible national industrial Reserve Army had emerged (Lutz 1984, 186pp.). It was, however, present, with a latent effectiveness. Women remained relatively excluded from full-time employment and reproductive work remained a free resource (Aulenbacher 2009), alongside the mobilization of migrants as 'guest workers'. From the perspective of integrated wage labourers, poverty and precarity appeared only at society's edges,

\footnotetext{
${ }^{5}$ 'Between the 1880s and 1970, the average real wages of industrial labour had more than tripled. Despite methodical problems in determining comparable real wages, we can record that the major changes took place in the decades after World War II' (Mooser 1984, 74).
} 
Socialist Studies / Études socialistes 6(2) Fall 2010: 43-74

phenomena from 'a different world'. A specific form of Landnahme released labour for the labour market, while limiting the extent to which such labour was considered a commodity by means of extended claims to social property,. This brought about an integrated class society with its centre of social gravity located among the middle classes (Wright 1985; 2000). In its conception of itself, this society was more of a house with permeable social levels (Geißler, 2006) than a polarized class structure. Social cohesion in this 'Society of the Similar' was reinforced by the existence of a competing 'twin model' based on state socialism that created social security but at the cost of individual and collective liberties (Wagner, 1995).

The integrated Fordist class societies were based on an 'inner Landnahme' of resources that have been used and cannot be restored. The Fordist Landnahme, a product of state intervention, displaced the traditional sector's characteristic products and services from the range of everyday needs of wage labourers and mobilized labour from the noncapitalist segments for industry and modern service provision. Both processes, amplifying each other, meant the 'progressive destruction of structures, forms of production, ways of living and behaviour orientations'. According to Lutz, this 'inner Landnahme' can be seen as analogous to the imperialist 'outer Landnahme' observed by Rosa Luxemburg (Lutz 1984, 213). The 'accumulation of political power' -- according to Hannah Arendt $(2006,312)$ a twin of capital accumulation but with the potential of developing an independent existence -- was domesticated and directed inwards, in contrast to early $20^{\text {th }}$ century imperialism. And this was only possible because it was based on recognition of 'workers' power' (Silver 2005)..$^{7}$

Fordist class societies' strong social integration was fundamentally based on the incorporation of proletarian power, especially in highly juridified welfare state systems. Wage labourers' structural and

\footnotetext{
${ }^{6}$ Translator's note: as the article is mainly based on observations from German society, the 'twin model' socialist state implied here is the German Democratic Republic.

${ }^{7}$ Following Fligstein's $(2001,67)$ typology, the 'architecture of markets' in Scandinavian countries is determined by coalitions between workers and the state, in the United States, the alliances are dominated by capital's interests, while in Germany, the coalitions are founded on compromises between organized interests of wage labourers and capital. Accordingly, the respective institutionalizations of 'proletarian power' have developed differently. In the voluntaristic labour relations systems of the liberal Anglo-saxon capitalisms, such institutionalization has remained at a low level. In contrast, the corporative capitalisms of the 'Rhine' type, in particular the German system of dual interest representation are characterized by a high level of institutionalized workers' power (Frege/Kelly, 2004).
} 
organizational power were partly replaced by institutional ones, i.e. power resources relatively independent of situational influences and sudden changes in the balance of power. The ruling class factions paid a political price to pacify industrial class conflict: namely, the recognition, incorporation and institutional continuity of proletarian power. The ambivalence of this type of integration became obvious in the late 1960s, when several countries in continental Europe saw reawakening worker militancy (Streeck 2003), a phenomenon totally unanticipated by mainstream sociology. The Landnahme by financial capitalism, which began in the mid-1970s, is also a reaction to this short-lived revival of organized proletarian power. Financial capital sought to re-occupy the 'outside' that Fordist capitalism had established through market-limiting institutions and the incorporation of working class power: a type of flexible accumulation combines with regulation prioritizing market personalities, individual responsibility and competitiveness in contrast to principles of solidarity and cooperation (Dörre 2009). One major result of the latest Landnahme by financial capitalism is the re-establishment of a visible Reserve Army mechanism within the developed capitalisms.

... and its revival.

Landnahmen are not linear processes: they are always based on contingent decisions, create friction and contradictions, provoke counter-movements and mobilize protest and resistance. Nevertheless, each mode of capitalist Landnahme has dominant characteristics whose effects become clear in long cycles of opening and closing markets. The finance-driven mode is based on the relative dominance of -often fictitious - investment capital. The so-called Dollar Wall Street Regime (Henwood 1994) and the United States currency policy, used to maintain its leading role in the global economy, was central to integrating constitutive elements of financial market capitalism into the continental European economies - with active support from European governments. American hegemony in the international system of states made it possible to introduce standards of financial capitalism into different types of capitalism. The consequence was that the principles of liquidity governing global financial markets were successively transferred to real economies and then virtually all domains of society (Boyer 2000; Castells 1996; Fligstein 2001).

A first major factor driving forward the restructuring of class conditions and class relations is located here. To adapt to volatile markets with rapid fluctuations and to guarantee expected profit margins in the longer term, wages, working hours and working conditions have been 
declared residual factors which can be flexibly adapted to the prevailing business climate. Market-dominating enterprises pass on the pressure of having to meet expected profit margins to management and personnel, to their suppliers and to dependent segments of small and medium-sized enterprises, which are also affected by specific transfer mechanisms. To make it possible for companies to 'breathe' in the flow of economic trends, flexible forms of employment and especially external flexibilization tools such as fixed-term employment, work contracts and temporary agency work are given greater significance in the value-creating systems. The regime of financial capitalism invents methods to increase promised profits by reviving secondary exploitation mechanisms. To make equity return rates on the order of twenty-five percent and even more, capitalist players seek extra profits via the precarization of employment (Chesnais $2004,236)$. The resulting competitive advantages are easily copied and therefore are not permanent; the 'engine' of this type of Landnahme must be kept running, requiring constant competitive undercutting, spin-offs, outsourcing, deregulation campaigns, with wage dumping and even repressive measures and the brutalization of the labour market. Growing insecurity in work conditions is the consequence of inflated promises and expectations of shareholder earnings and profits.

While the Fordist Landnahme was mainly based on an expansive welfare state and a high degree of de-commodification of wage labour, the finance-driven Landnahme seeks to improve the dynamics of accumulation without any further development of the welfare state. Nevertheless, the modus operandi of this Landnahme cycle cannot be reduced to simple privatization and deregulation. Rather, the new Landnahme is rooted in microsocial structures such as the single-income family. In West Germany, this Landnahme was always also politically staged. Many discriminating structures have eroded, thus ensuring improvements in women's integration in education and employment, with significant support from the women's movement. Of course, the potential of free female labour could and still can be used to reactivate the very Reserve Army mechanism that, for a short period, seemed to have been neutralized in capitalism's core countries with their organized labour markets. Such a reactivation became possible because dominant capitalist players (companies, managers, owners) offensively used the option of establishing competitiveness by means of overexploitation and a brutalization of the labour market. Moreover, comparatively speaking, women were more prepared to accept precarious working conditions, particularly in a situation where re-commodifying labour market and social policies made 
DÖRRE: Social Classes in the Process of Capitalist Landnahme

such an asymmetrical employment structures for women possible (Streeck 2005; Aulenbacher 2009).

\section{The Landnahme of Financial Capitalism and Precarization}

Overall, financialization and precarization have initiated the transition from a socially integrative class society to a more strongly polarized one. Yet, the socially cohesive class society of social-bureaucratic capitalism has not entirely vanished. In the form of normal employment relationships, regulating institutions and habitualized dispositions, it still influences the demands and action strategies of individual and collective players to some degree. It is a tension-filled co-existence of old and new structures that currently determines the process of restructuring class relations. In spite of all the continuities, a new kind of social reality is developing. This becomes clear if we pay attention to how, in the course of the Landnahme of financial capitalism, the relations between classes (class factions) and the dynamics of conflict embedded in them have developed.

The re-structuring and re-positioning of the ruling classes

The latest Landnahme is an international and trans-national process. One of its consequences is an internationalization of class relations among the ruling class factions, albeit with many contradictions. In fact, some analyses (Sklair 2008, 213-240) postulate the emergence of trans-national ruling classes, identifying a meta-network of industrial complexes, think tanks, élite schools and consulting businesses that integrate capitalist interests at the global level across all sectors and fields of activity (Castells 2001, 533). Others remain more sceptical. Yet so far, a homogeneous, truly international ruling class does not exist. What applies to all ruling class factions and élites is that their mode of reproduction is - still - limited nationally or regionally.

The continuing dependence on national power resources and the need to find national compromises also explains why, in the leading nations of the capitalist world, the bourgeoisie still recruits among its own ranks to a great extent (Hartmann 2008, 241-258). So although there is some social and cultural homogeneity in current class formations, the forms of business management corresponding to the Landnahme project of financial capitalism imply fractions, conflict and discontinuity within the ruling classes. Shareholder-oriented business management created a new kind of managerial élite that feels no obligation towards collective company expectations and is not prepared to be pinned down to any growth targets. Instead, these new types of managers expect a high degree 
Socialist Studies / Études socialistes 6(2) Fall 2010: 43-74

of correspondence between their own interests and company interests and place the pursuit of short-term profit maximization at the centre of their actions (Fligstein 2001). Contrary to its actual intentions, shareholdervalue-driven management has not limited the scope of top managers' actions; in many ways the opposite has happened. The model of efficient shareholder-value-driven management is not realizable in its pure form, not least because the level of control promised is impossible to exercise in practice (for a classic analysis see Berle 1963, 28).

The interests of financial capitalism have broadened. Political measures to deregulate financial relations contribute to the formation of particular 'service-providing classes' of financial market capitalism (Windolf 2008 516-535) who have an interest in making the structures of financial capitalism permanent. The specific rationality of the finance sector has brought about a multitude of services and functions which, for better or for worse, are inextricably tied to the mechanisms of this regime. Indeed, the logic of financial market capitalism promises 'to make many people wealthy': managers whose income grows disproportionately along with the share prices due to options, or investment bankers, business consultants or lawyers who make a killing with possible capital market transactions (Frankfurter Rundschau, 23 June 2006). National contexts still matter, however: top managers of companies based in Germany, who earn more than a hundred times what a skilled worker earns, still fall far behind the highest salaries of American CEOs, who even back in 2003 earned up to four hundred times the income of qualified workers (Dörre/Brinkmann 2005, 105; Reich, 2010, 49-56).

Thus, the transition to financial market capitalism represents a range of trans-national class projects aiming in a similar direction, although they vary depending on the respective national regulation systems. The objective of these projects is primarily to re-establish the power of ruling class factions (Harvey 2005). Their leverage -estimated returns and profits which cannot be realized in the real economy- results in structural pressure for the re-distribution of income and wealth. Government policies, only taking into account the economic dimension of this Landnahme of financial capitalism, reinforce the pressure for recommodification. Thus, the red-green coalition government in Germany under Chancellor Schröder in its second term of office was a pioneer in deregulating financial markets (e.g. abandonment of the tax on capital gains from transfers) and moreover, supported this policy with measures broadly expropriating the social capital of large groups of wage-dependent employees. In this way, the Landnahme of financial capitalism furthers 
integration into a flexible and market-centred way of production whose functionality is based on reviving of the Reserve Army mechanism.

Extending the risk zone of financial capitalism has the negative consequence of the far-reaching precarization of work and employment. In this, the active labour market regime takes on a function similar to that of post-feudal punitive laws (Marx) and workhouses (Foucault) during the transition to early capitalism. By sanitizing the image of precarious work and increasing the pressure to work, this regime creates a disciplining strain which is supposed to stimulate (potential) employees to find employment in a highly polarized working world.

Decline of the status of workers and secondary exploitation: In these developments, one glimpses a break in continuity which in terms of class structure is as significant as the change of property conditions and class relations at the hierarchic peak of financial capitalism. This applies in particular to the mass of workers. If social-bureaucratic capitalism was accompanied by the collective ascent of workers, the expansion of the world market for production locations, the changes in social structures and the erosion of social citizenship status are now bringing about a collective decline for this mass. 'Rationalization' and labour market risks are increasingly affecting groups of qualified workers and also employees, who for a long time considered themselves and their contribution to society's productivity more or less indispensable.

At the same time, an ideology which places success above performance is shaking up previously common conceptions of upward mobility. The belief that one's own situation and that of the following generation will improve slowly but continuously, that prosperity and security will continue to grow perpetually, has been damaged substantially. The notion that organization of supra-individual interests and joint action, i.e. conscious class action, can be prerequisites of a collective ascent is fast disappearing in Germany and other countries in continental Europe. Social ascent appears possible only as an individual, by means of self-assertion in a competitive environment. The resulting social orientations stimulate classification struggles within the working classes and forms of dissociation from supposedly 'parasitic' parts of society. The large group of industrial workers is at the centre of this development. Formally, workers in Germany are still a large - although shrinking - social group at over $28 \%$ of the overall workforce in 2008 . But, ethnic stratification shows that the internal structure of this large group and therefore presumably also the respective social self-definitions and 
interest orientations have changed substantially. ${ }^{8}$ As a consequence of structural changes and the Landnahme of financial capitalism, the status of worker has dramatically lost its social attractiveness; for this reason, more and more labour with a migrant background is mobilized, a class fraction for whom employment in even the least attractive segments may still mean an improvement.

What is crucial, however, are the habitual and social-psychological dimensions of this collective decline. Workers and employees in a permanent employment position tend to defend the social property they still have at their disposal. The reproduction strategies of these permanent employees thus have a conservative quality. It is quite understandable that these groups tend to defend their own secure employment situation. Such a conservative basic attitude, which often dominates the actions of employee representation, facilitates the solidification of a mechanism of secondary exploitation designed as economic and political precarization strategies. To avoid any misinterpretations: permanent employees and their works councils are no exploiters. Under competitive pressures, they accept company strategies that shunt the employment risk in the direction of the heterogenous group of people in flexible or precarious employment. Along with changes to the function of precarious employment (Holst et al. 2010), the social effects of occupational corporatism whose origins reach back to the era of Fordist capitalism are also undergoing a change. The relatively - safe employment situation of one group of employees is maintained at the cost of growing insecurity for other groups. Mere defense of the advantages of internal labour markets, a response to the threat of the Reserve Army of Labour, thus chops away at the social property of precarized groups whose power resources are weak anyway.

Return of the subproletariat and the spreading of secondary exploitation The stronger such defensive class faction self-protection policies, the more likely the return of a modified subproletariat dynamic. The current structural forms of precarity permeate all 'zones of social cohesion' (Castel 2000) and can be found within different classes (class factions) and levels (Castel 2009, 30-31). There is neither a homogeneous underclass nor a clearly discernible precariat (Pelizzari 2009, 119-158). Instead, different kinds of precarity with different characteristics can be identified (Castel/Dörre 2009). Precarious employment may mean that the actual

\footnotetext{
${ }^{8}$ Among those with an immigrant background, workers comprise $46.6 \%$ of the population (Statistisches Bundesamt 2008).
} 
work is creative. On the other hand, the work content in a secure full-time job can be very unsatisfying, monotonous and burdensome (Paugam 2009, 175-196). Precarity of work and precarity of employment can also coincide structurally without being perceived as such subjectively. In some cases, precarity is a temporary situation, a status passage on the way to a better social position, while in other cases, the precarious situation becomes permanent. The latter primarily applies to groups at the bottom end of the social hierarchy, the ones Marx (Marx 1867: 623pp.) called the 'surplus population' of the capitalist labour society. ${ }^{9}$

A distinction can be made between this 'surplus population' and the actual precariat. What is meant by the latter term is growing groups which, over longer periods, are dependent on working in unsecured, badly paid and socially despised jobs. The increase in atypical employment relationships (temp work, short-term employment, part-time work, minor employment) by $46.2 \%$ (1998-2008) is an indicator of this trend towards precarization, although an unreliable one. Not every atypical employment situation is necessarily precarious. Still, non-standardized employment relationships are generally associated with noticeably lower income as well as higher risks of unemployment and poverty (Statistisches Bundesamt, 19 August 2009). In Germany in 2008, 7.7 million employed persons were in an atypical employment relationship (as compared to 22.9 million in normal employment). In 2008, there were 2.1 million selfemployed (ibid.) as well as a steep rise in low-wage full-time employment (11.1 percent of those in normal employment in 2006, i.e. 1.6 million people). Meanwhile, about 6.5 million people in Germany earn less than two thirds of the median wage (Bosch/Weinkopf 2007). A total of $42.6 \%$ of low-wage earners worked in a normal employment relationship. Among these, the largest groups are women (30.5\%) in service jobs and individuals with few qualifications. Yet about three quarters of all people in low-wage employment had completed professional training or possessed an academic degree (Kalina/Vanselow/Weinkopf 2008, 20-24). It is symptomatic that precarious situations are becoming more permanent that upward mobility in the German low-wage sector is declining despite such qualifications (Bosch/Kalina 2007, 42 pp.).

\footnotetext{
${ }^{9}$ In Germany, among these one finds the majority of the over 2.2 million long-term unemployed (as of July 2009) along with their families, as well as nearly 1.1 million in employment whose income is insufficient to live on without social transfers (Bundesagentur für Arbeit 2009). Together with their respective families, this amounts to over seven million people.
} 
Socialist Studies / Études socialistes 6(2) Fall 2010: 43-74

Of particular significance is the fact that within ten years (19972007), the bottom quarter of wage-earners shouldered a fourteen percent loss in real income (Statistisches Bundesamt, 19 August 2009). While wagedependent employees in relatively secure employment were able to maintain their living standard or at least limit the losses, the gap between the precarious strata and social 'normality' is getting wider. This development illustrates the effectiveness of secondary exploitation mechanisms. Collective protection mechanisms traditionally have the greatest effect where organised labour interests were and still are comparatively easy to assert - in the public sector and in large companies with a high percentage of mostly male full-time employees. What is new, though, is that traditional forms of precarity e.g. among women and migrants, increasingly blend with the precarization experiences of previously secure groups. The fear of losing status is also becoming common among some elements of those in normal employment. Such concerns do not necessarily correspond to objective threats, but they are not simply evidence of exaggerated notions of security, either. Competition between business locations, loss in real wages and the slow but steady undermining of collective agreements, and therefore of institutional power, generate concerns, even among the wage-dependent employees who are core union members, that the days of being able to catch up to the middle classes may be over. Given a shrinking income gap between the lower and middle classes and growing labour market risks, there are fears of losing one's livelihood even at the very 'core of the middle class' (Werding/Müller 2007, 157; DIW, 05. March 2008).

\section{Revival of the Reserve Army mechanism}

At this point, whether we are already in a situation of class division between, on the one hand, a working class in still relatively secure employment fighting for its remaining social property and, one the other hand, a heterogeneous subproletariat which is currently unable to form its own political class, is an open question. What is certain, is that the revival of a visible Reserve Army mechanism is forcing adaptation to a new mode of social integration and dominance. Replacing a kind of integration that was substantially based on material and democratic participation and on the incorporation of proletarian power are new forms of integration in which the subtle effects of market-type disciplining methods state pressure are much more prominent. By disciplining one part of society and depriving another of their elementary means of resistance, this strategy stabilizes instability. The excluded and precarized are manifestations of a 
fate that wage-dependent groups who are still integrated seek to avoid. Not only abstract market conditions function as a disciplining force, the victims of market-driven management, i.e. the precarized groups, have the same kind of impact. They serve as examples to those still in a secure position of what can happen if one gets caught in the maelstrom of collective downward mobility. Thus, subjective insecurity reaches well into the ranks of those who are formally secure, supporting a system of control and disciplining that even integrated wage-dependent employees find it difficult to ignore.

Companies readily exploit fears of precarization and implement flexibilization strategies that create two types of wage-earners. The strategic use of temporary agency work (Holst et al. 2009), as practised by so-called 'excellent companies', is only one example of this. Strategic use means that even when a business is performing well, temp workers are constantly present. They perform the same jobs as permanent employees, yet for wages which on average are thirty to fifty percent lower. Protection against layoffs no longer exists for these groups, in principle, as the latest global crisis shows. The companies using temp workers save on layoff costs, and large temp companies achieve exorbitant profits at the expense of precariously employed, 'second-class' wage-earners. The less than three percent temp workers among the workforce are merely the tip of the iceberg. In the precarious employment sector, different forms of regulation of social and labour relations have become dominant, even concerning relatively protected areas like wage agreements. Increasingly, in the precarious sector, the commodities exchanged are 'repression against fear' (Artus et al. 2009). Along the lines suggested by Rosa Luxemburg, this system is indeed a socially generated 'Other' where authoritarian rule by superiors, disciplining pressure, perversion of justice and today, electronic monitoring are superimposed or completely replace the regulated exchange of labour for fair wages. No less significant is the fact that precarization is also becoming an increasingly serious factor in the reproduction sector. Flexible working conditions and individualized forms of living generate the need for care work, which in Germany is performed mainly by women and, in addition, mostly unpaid. The woman with an academic degree in a double-income household who informally employs a Polish maid who is also academically educated stands as a symbol of this development. What temporary agency workers are to industrial production is represented by the '24/24 live-in Polish maid' (Lutz 2007, 210-235) in private households. 
Socialist Studies / Études socialistes 6(2) Fall 2010: 43-74

\section{A Few Conclusions}

Overall, the outlines of the new class relations of financial capitalism are clear. What constitutes this restructuring are, first of all, changes at the top of the class hierarchy. In societies where wealth is increasing and the number of wealthy persons is growing, there is surplus capital available waiting for investment opportunities. Under the conditions of structural over-accumulation in the leading sectors of the global economy, this is a fundamental cause of the expansion and relative autonomization of the financial sector. Both provide a fertile ground for a rearrangement of ownership structures and of corporate governance in business. The Landnahme of financial capitalism strengthens the autonomy of those parts of management capable of strategic thinking, while broadening the social basis of the ruling class faction. The aggregate functional and service divisions of the financial sector are operated by high-income groups whose interests are organically linked to this project of financial capitalism. The project can only function, if impossible-to-realize promises of returns and profits are realized in a different way, outside of the real economy. This is what the core idea of the Landnahme of financial capitalism is about. To keep the engine of flexible accumulation running, unused assets are fed into the capital cycle. To this end, institutions limiting the market are 'razed', social property cut down or simply disowned, and secondary exploitation perpetuated. Parts of the potentially employed population are systematically pushed below the working and living conditions of their class; precarization is thus merely the negative face of a functioning system of accumulation in financial capitalism.

In addition to economic disciplining mechanisms, there are also political ones implemented by the state to ensure that the flexible production methods based on divided labour markets have adequate 'human resources' at their disposal. Although the institutionalization of mechanisms of secondary exploitation represents a class project 'from the top', workers and employees threatened by structural changes and competition between business locations tend to defend the 'privilege' of permanent employment with teeth and claws. For this reason, in a crisis situation, they are ultimately prepared to accept that employment and income risks are mainly passed on to others as flexible and precarious employment, a position often taken in agreement with those representing their interests. This tendency may appear self-evident and understandable given limited options, but the consequence is that lines of division and segmentation solidify and may well in the future turn out to become a specific form of class division. Precarized groups represent 'the outside' of 
labour protected by the welfare state, a particular class of conditions of existence enduring beside the system of primary capitalist exploitation while at the same time influencing it substantially.

Faced with the reality of a precarious sector structured by fear and repression, workers and employees in permanent employment frequently make use of corporatist action strategies from the days of 'social capitalism', yet these have a completely different effect under the conditions of financial capitalism. What is actually intended as disciplining measures and over-exploitation in the interest of ruling class factions appears on the surface as a division of interests between those in permanent employment on the one hand and of precarized or unemployed groups on the other.

The relative stability of financial capitalism's power structure, its characteristic class relations, can be qualified as showing post-democratic tendencies. The social power of the 'financial aristocracy' (Marx 1894, 435) does not stimulate heterodox class power among the ruled classes. On the contrary, for 'people who are not part of the increasingly more confident class of shareholders and top managers' it has become more difficult in the last decades 'to perceive themselves as a clearly defined social group' (Crouch 2008, 71, translated from the German edition). To put it bluntly: by means of disorganization, precarization and the sheer wearing out of actors, the Landnahme of financial capitalism reduces the possibilities of forming an effective opposition. There is no concrete antagonist in a position to actually politically challenge the ruling elites.

Whether and in what way these post-democratic mechanisms of self-stabilization of financial market capitalism can be eliminated is a matter a class analysis, an analysis that may be usefully informed by Rosa Luxemburg's theory of emancipation. Without a concrete answer, it is nonetheless clear that the relations between integrated and disintegrated social groups have become a key problem of any alternative grass-roots class project. This project is only possible if the inside-outside dialectics of capitalist development are reflected in an intellectual analysis that recognizes the particular characteristics of precarized groups and does not attempt to integrate them prematurely into structures corresponding to Marx's unified political class. To achieve this, the simultaneity of the nonsimultaneous inherent in any Landnahme cycle must be analysed. As a contribution towards such a goal, six considerations are presented here.

First, the Landnahme of financial capitalism has substantially altered the grammar of social conflict. The pacified and institutionalized class conflict of 'social capitalism' (Sennett 2007, 27) is fragmenting. In the 
Socialist Studies / Études socialistes 6(2) Fall 2010: 43-74

struggle for social property, lines of conflict emerge which are clearly different from the standardized struggles and negotiations of the Fordist era. Along with the decline of organized labour relations in some sectors and developed countries, new labour movements appear in countries and regions of the global south (Brinkmann et al. 2008, 56-63). What is crucial is that even in developed countries, collective (labour) interests are often articulated outside the scope of normalized conflict. In abandoned neighbourhoods and regions, 'bargaining by riots' is quite common, a practise which despite the undeniable relevance of ethnic or genderspecific constructions, originates to a great extent in spontaneous or unconventionally organized class action (Wacquant 2009). A good part of the uprisings in French or British suburbs are class-specific 'bread' conflicts in which feelings of powerlessness and pent-up anger are discharged in militant action. The reawakened militancy of young, welleducated Greeks or the protest of French workers against layoffs taking the form of 'bossnapping' illustrate that the traditional forms of conflict regulation through intermediaries do not work anymore for many social groups, even in the core countries of capitalism. The stronger the pressure applied to institutionalized forms of proletarian power becomes, the greater the preparedness of sparsely organized groups to articulate their anger, disappointment and frustration in spontaneous, non-normative conflicts - a phenomenon which under a completely different historic perspective was already observed by Rosa Luxemburg (1906/1974, 91170).

Therefore, second, a new kind of class analysis must consider the phenomenon of non-normative conflicts and deal with all forms of labour unrest (Silver 2003), with spontaneous outrage, uprisings, i.e. with the nasty side of class struggles which take place in every Landnahme cycle and which - not always, but frequently - happen outside the world of organized labour. To acknowledge this does not mean encouraging a discourse on pauperization and idealizing non-normative conflict. Yet an illusion-free glance beyond the boundaries of developed capitalist countries clearly shows that in many societies of the south, the nasty side of social conflict is a reality for the majority. Even in capitalism's core countries, the attitude of comparatively secure groups, and especially that of permanently employed workers threatened by decline has become a key political matter. The bloc formation of financial capitalism focussing on the social mainstream seeks to protect prosperity and social property by withdrawing the solidarity of the welfare state from the underclasses that are supposedly unwilling to perform and be upwardly mobile (Nolte 2006, 
$100 \mathrm{pp}$.). Alternative class projects thus need to begin with a cautious analysis, looking for and identifying similarities shared in the long term by integrated and precarized groups.

In this context it is, third, important to critically review the re- and devaluation of social groups along with their collective action strategies based on modernization theory. There can be no doubt that precarization weakens the ability to resist and protest. Bourdieu's $(2000,100$, translated from the German edition) notion that precarized groups, 'due to a lack of security and stability' cannot 'envision a complete change of social order (which) would be required to eliminate the root causes of misery in the first place' applies to the modern 'precariat' as well as the Kabylian subproletariat. Still, the precarized classes of financial market capitalism have little in common with the lumpenproletariat Marx observed in the early days of industrial capitalism. Without wallowing in social romanticism, it is clear that precarized groups such as the youngsters of the French banlieues do in fact have their own interest organization and forms of protest (Candeias 2009, 369-380). Electronic means of communication provide them with forums and networking possibilities. In many countries, (class) action of such precarized groups through selforganization, e.g. within trade unions, is already a genuine option (Tait 2005; Brinkmann et al. 2008, 135-140). The analytical question of whether the new 'precariat' is dead political capital or a potential agent of new-style class movements is a matter for intensive future investigation.

A critical revision of simple attributions of modernization theory, fourth, implies that the parallel existence of different production methods and class conditions must have systematic repercussions, including ideologically. The power to define flexible forms of employment lies to a great extent with professional groups to whom such employment conditions have been a part of everyday life for quite some time (journalists, media people, scientists). These groups are much more likely to find satisfaction in models of unconventional integration than in the ideal image of protected wage labour. Moreover, the message of the liberating effect of flexible employment is interesting to other groups well beyond the domain of the middle classes. A freelancer in the sector of professional development, a self-employed media specialist or a scientist with unclear career prospects will do their utmost to find positive aspects in their structurally precarious status and to develop forms of living to compensate for possible disadvantages. It is unlikely that such groups will develop much understanding for policies exclusively aimed at protecting conventional full-time employment. 
Socialist Studies / Études socialistes 6(2) Fall 2010: 43-74

When a supposedly traditional orientation towards normal employment relationships is criticized in public discourse and there is a demand for an unprejudiced look at the 'liberating' potential of unsecure employment as an alternative, fifth, such definitions are established from specific class positions. They reflect the borderline case of 'creative precarity'. Such a view becomes problematic, however, as soon as it is treated as an exclusive perspective. A simple bipolar construction (normal employment = male and white; precarious employment $=$ female and ethnic minority) may lead to a situation where the employees' need for conventional security is, at least subliminally, classified as an atavistic relic from the 'golden years' of Fordist capitalism. But even if it were the case that the dream of - let us say a male, white - temp worker of becoming a permanent employee merely extends to a habitualization of Fordist concepts of security, it would be extremely problematic to deny this demand's legitimacy. Yet this delegitimation of an actual source of suffering is exactly what takes place if so-called traditional needs for protection are put in opposition to an allegedly modern concept of 'contingency coping' (Lessenich/van Dyk 2008). The discursive construction of a temp worker caught up in the past (and of the scientists referring to that worker) is similar to the situation of Bourdieu's Algerian subproletarians who are measured according to the modern ideal of production methods in which they are unable to function rationally due to a lack of opportunities and resources.

Instead of analytically duplicating such mechanisms of symbolic rule, it is necessary to sixth take a more precise look at the current forms of secondary exploitation. Their reciprocal effect with exploitation in 'interior markets' should not be seen as static. Along these lines, the new feminist movement's political achievements were made in the context of a pacified industrial class conflict, making it possible to delegitimize a specific form of secondary exploitation. Insofar as feminist demands are limited to individual integration in flexible employment situations, however, they risk becoming an ideological justification of precarization and the Landnahme of financial capitalism (Fraser 2009). This is possible because the collective success of occupational integration has increased the social differentiation of women. There is a class-specific hierarchical relationship between, e.g., a female company manager and a (female) housekeeper which cannot be categorized in terms of gender relations. On the other hand, e.g. the twenty per cent difference in income between men and women which still is a reality in Germany cannot be explained by class analysis. To detect subtle reciprocal relations between different forms of 
exploitation, it makes sense to follow up, among other sources, various contributions to the debate on intersectionality (Anderson et al. 1998). In the long term, this may contribute to an intellectual analysis establishing an innovative link between class policies and anti-discrimination policies.

The Landnahme cycle has now passed a critical point of selfdynamization. With the end of the era of fossil energy drawing near and climate change becoming more obvious, the ecological and social limits of this 'perpetual motion' (Luxemburg 1913,11) are clear. Basically, there are only two solutions: 'One is to make growth sustainable; the other is to make de-growth stable' (Jackson 2009, 128). A theory-guided class perspective will not become irrelevant once the capitalist pressure for growth are surpassed. On the contrary, class-specific concerns about security and notions of justice can be combined with concepts of prosperity without conventional growth. This is necessary because precarization and social exclusion make acquiring a more long-term awareness of the future and thus also of developing a sustainable life-style more difficult if not completely impossible. At the same time, an ecologically motivated social transformation is easier to achieve in societies with comparatively egalitarian structures. Thus, it makes sense to set out, analytically, the prospects of a 'grass-roots class project 'which seeks to achieve a 'Landpreisgabe', an 'abandonment of territories'. In particular, Luxemburg's work is a useful starting point for such a project.

\section{Acknowledgements}

I wish to thank Mat Dressler/COMPACT, who did his very best with the translation. Two anonymous consultants gave me helpful suggestions for a revised version. Most cordially, I would like to thank Elaine Coburn, who provided additional editorial assistance in ensuring the translation met standards required for an international journal.

\section{References}

Andersen, Margaret L. and Patria Hill Collins, eds. 1998. Race, Class and Gender. An Anthology. London: Third Edition.

Arendt, Hannah. 1958. The Origins of Totalitarianism. New York: Meridian (Germ. 2006. Elemente und Ursprünge totalitärer Herrschaft. Antisemitismus, Imperialismus, totale Herrschaft [1951]. 11. Aufl. München: Piper.).

Artus, Ingrid, Sabine Böhm, Stefan Lücking and Rainer Trinczek. 2009. Jens eits der Mitbestimmung. Interessenhandeln in Betrieben ohne Betriebsrat. Frankfurt/New York: Campus 
Aulenbacher, Brigitte. 2009. 'Die soziale Frage neu gestellt - Gesellschaftsanalysen der Prekarisierungs- und Geschlechterforschung.' In: Robert Castel and Klaus Dörre, eds. Prekarität, Abstieg, Ausgrenzung. Die soziale Frage am Beginn des 21. Jahrhunderts. Frankfurt a.M./ New York: Campus: 65-80.

Beck. Ulrich. 1983. 'Jenseits von Stand und Klasse.' In: Kreckel, Reinhard, ed. 1983. Soziale Ungleichheiten. Soziale Welt Sonderband 2. Göttingen: Schwartz, S. 35-53.

Berle, Adolf. 1963. The American Economic Republic. New York: Harcourt.

Bosch, Gerhard and Thorsten Kalina. 2007. 'Niedriglöhne in Deutschland - Zahlen, Fakten, Ursachen.' In: Gerhard Bosch and Claudia Weinkopf, eds. Arbeiten für wenig Geld. Niedriglohnbeschäftigung in Deutschland. Frankfurt a.M.: 20-105.

Bosch, Gerhard and Claudia Weinkopf, eds. 2007. Arbeiten für wenig Geld. Niedriglohnbeschäftigung in Deutschland. Frankfurt a. M./ New York: Campus.

Bourdieu, Pierre. 2000. Die zwei Gesichter der Arbeit. Interdependenzen von Zeit- und Wirtschaftsstrukturen am Beispiel einer Ethnologie der algerischen Übergangsgesellschaft. Konstanz: UVK Verlagsgesellschaft.

Bourdieu, Pierre. 2002. Masculine Domaination. Stanford: University Press (Germ. 2005. Die männliche Herrschaft. Frankfurt a.M.: Suhrkamp.).

Boyer, Robert. 2000. 'Is a finance-led growth regime a viable alternative to Fordism? A preliminary analysis.' In: Economy and Society 29. 1: 111-145.

Braudel, Fernand. Sozialgeschichte des 15.-18. Jahrhunderts: Vol. 1. 1985. Der Alltag. Vol. 2. 1986. Der Handel. Vol. 3. 1986. Aufbruch zur Weltwirtschaft. 1986. München: Kindler.

Brinkmann, Ulrich, Hae-Lin Choi, Richard Detje, Klaus Dörre, Hajo Holst, Serhat Karakayali, and Catherina Schmalstieg. 2008. Strategic Unionism. Aus der Krise zur Erneuerung? Wiesbaden: VS-Verlag.

Bundesagentur für Arbeit, ed. 2009. Statistik. Arbeitslose nach Rechtskreisen. July 2009.

Candeias, Mario. 2009. 'Von der Anomie zur Organisierung: Die Pariser Banlieue.' In: Robert Castel and Klaus Dörre, eds. Prekarität, Abstieg, Ausgrenzung. Die soziale Frage am Beginn des 21. Jahrhunderts. Frankfurt a.M./ New York: Campus: 369380.

Castel, Robert. 2000. Die Metamorphosen der sozialen Frage. Eine Chronik der Lohnarbeit. Konstanz: Universitätsverlag Konstanz.

Castel, Robert. 2002. From Manual Workers to Wage Laborers: Transformation of the Social Question. New Jersey: Transaction Publishers. 
DÖRRE: Social Classes in the Process of Capitalist Landnahme

Castel, Robert. 2005. Die Stärkung des Sozialen. Leben im neuen Wohlfahrtsstaat. Hamburg: Hamburger Edition.

Castel, Robert. 2009. 'Die Wiederkehr der sozialen Unsicherheit.' In: Robert Castel and Klaus Dörre, eds. Prekarität, Abstieg, Ausgrenzung. Die soziale Frage am Beginn des 21. Jahrhunderts. Frankfurt a.M./ New York: Campus: 21-34.

Castel, Robert ans Klaus Dörre, eds. 2009. Prekarität, Abstieg, Ausgrenzung. Die soziale Frage am Beginn des 21. Jahrhunderts. Frankfurt a.M./ New York: Campus.

Castells, Manuel. 1996. The rise on the network society. The information age: economy, society and culture, vol. 1. Cambridge: Blackwell.

Chesnais, Francois. 2004. 'Das finanzdominierte Akkumulationsregime: theoretische Begründung und Reichweite.' In: Christian Zeller, ed. Die globale Enteignungsökonomie. Münster: Westfälisches Dampfboot: 217-254.

Crouch, Colin. 2005. Post-democracy. Cambridge: Polity Press (Germ. 2008. Postdemokratie. Frankfurt a.M.: Suhrkamp.).

DIW-Wochenbericht 10-2008 from 5 March 2008.

Dörre, Klaus. 2009. 'Prekarität im Finanzmarkt-Kapitalismus.' In: Castel, Robert and Klaus Dörre, eds. Prekarität, Abstieg, Ausgrenzung. Die soziale Frage am Beginn des 21. Jahrhunderts, Frankfurt a.M./ New York: Campus: 35-64.

Dörre, Klaus and Bernd Röttger. 2006. Im Schatten der Globalisierung. Strukturpolitik, Netzwerke und Gewerkschaften in altindustriellen Regionen. Wiesbaden: VSVerlag.

Dörre, Klaus and Ulrich Brinkmann. 2005. 'Finanzmarktkapitalismus - Triebkraft eines flexiblen Produktionsmodells?' In: Kölner Zeitschrift für Soziologie und Sozialpsychologie (Sonderheft: Finanzmarktkapitalismus. Analysen zum Wandel von Produktionsregimen): 85-116.

Engels, Friedrich. 1972. Die Lage der arbeitenden Klassen in England. Nach eigner Anschauung und authentischen Quellen. In: MEW 2. Berlin: Dietz Verlag: 225-506.

Fligstein, Neil. 2001. The Architecture of Markets. An Economic Sociology of Twenty-FirstCentury Capitalist Societies. Princeton: Princeton University Press.

Foucault, Michel. 1996. Wahnsinn und Gesellschaft. Frankfurt a.M.: Suhrkamp.

Fraser, Nancy. 2009. 'Feminismus, Kapitalismus und die List der Geschichte.' In: Blätter für deutsche und internationale Politik 8/09: 43-57. 
Frege, Carola. M. and John Kelly, eds. 2004. Varieties of Unionism. Strategies for Union Revitalization in a Globalizing Economy, Oxford.

Geißler, Rainer. 2006. Die Sozialstruktur Deutschlands. Zur gesellschaftlichen Entwicklung mit einer Bilanz zur Vereinigung. 4. Aufl. Wiesbaden: VS-Verlag.

Gramsci, Antonio. 1998. Selections from the prison Notebooks. London: Lawrence \& Wishart Ltd. (germ. 1991. Gefängnishefte. Vol. 1. Kritische Gesamtausgabe. Heft 1. 1999.Vol. 9. Kritische Gesamtausgabe. Hefte 22-29. Hamburg: Argument Verlag.

Hartmann, Michael. 2008. 'Transnationale Klassenbildung?' In: Berger, Peter A. and Anja Weiß, eds. Transnationalisierung sozialer Ungleichheit. Wiesbaden: VS-Verlag: 241-258.

Harvey, David. 2003. The New Imperialism. Oxford: Oxford University Press.

Harvey, David. 2005. A Brief History of Neoliberalism. Oxford: Oxford University Press.

Henwood, Doug. 1994. Wall Street: How It Works and for Whom. New York: Verso.

Holst, Hajo, Oliver Nachtwey and Klaus Dörre. 2010. The Strategic Use of Temporary Agency Work - Functional Change of a Non-standard Form of Employment. In: International Journal of Action Research 6(1): 108-138.

Hyman, Richard and Rebecca Gumbrell-McCormick. 2010. 'Trade Unions and the crisis: a lost opportunity?' In: Socio-Economic-Review 2010/8.

Gubitzer, Luise. 2006. 'Wirtschaft ist mehr. Sektorenmodell der Gesamtwirtschaft als Grundlage für Geschlechtergerechtigkeit.' In: Widerspruch. no. 50:17-29.

Kalina, Thorsten, Achim Vanselow and Claudia Weinkopf. 2008. 'Niedriglöhne in Deutschland.' In: Sozialistische Politik und Wirtschaft. no 164: 20-24.

Lessenich, Stephan and Silke van Dyk. 2008. Unsichere Zeiten. Die paradoxale >Wiederkehr< der Unsicherheit. Mittelweg 36, Jg. 17, no. 5: 13-45.

Lutz, Burkart. 1984. Der kurze Traum immerwährender Prosperität. Eine Neuinterpretation der industriell-kapitalistischen Entwicklung im Europa des 20. Jahrhunderts. Frankfurt a.M./ New York: Campus.

Lutz, Helma. 2007. 'Die 24-Stunden-Polin'- Eine intersektionale Analyse transnationaler Dienstleistungen. In: Cornelia Klinger, Gudrun-Axeli Knapp Birgit Sauer, eds. Achsen der Ungleichheit. Zum Verhältnis von Klasse, Geschlecht und Ethnizität. Frankfurt a. M.: Campus: 210-235.

Luxemburg, Rosa. 1906. Massenstreik, Partei und Gewerkschaften. In: Gesammelte Werke Vol. 2. Berlin. 1974: 91-170. 
DÖRRE: Social Classes in the Process of Capitalist Landnahme

Luxemburg, Rosa. 1913. The Accumulation of Capital. London, New York: Routledge 2003.

Marx, Karl. 1867. Capital, Vol. I - The Process of Production of Capital. In: Marx Engels Collected Works, Vol. 35. New York 1997: International Publishers.

Marx, Karl. 1894. Capital, Vol. III - The Process of Capitalist Production of as a Whole. In: Marx Engels Collected Works, Vol. 37. New York 1997: International Publishers.

Milkman, Ruth. 2010. 'The US labour movement and the audacity of hope.' In: SocioEconomic-Review 2010/8.

Nolte, Paul. 2006. Riskante Moderne. Die Deutschen und der Neue Kapitalismus. München: Beck.

Mooser, Josef. 1984. Arbeiterleben in Deutschland 1900 - 1970. Frankfurt a.M.: Suhrkamp.

Paugam, Serge. 2008. Die elementaren Formen der Armut. Hanburg: Hamburger Edition.

Paugam, Serge. 2009. 'Die Herausforderung der organischen Solidarität durch die Prekarisierung von Arbeit und Beschäftigung.' In: Robert Castel and Klaus Dörre, eds. 2009. Prekarität, Abstieg, Ausgrenzung. Die soziale Frage am Beginn des 21. Jahrhunderts. Frankfurt a. M./ New York: Campus: 175-196.

Pelizzari, Alessandro. 2009. Dynamiken der Prekarisierung. Atypische Erwerbsverhältnisse und milieuspezifische Unsicherheitsbewältigung. Konstanz: UVK.

Piore, Michael J. 1983. 'Internationale Arbeitskräftemigration und dualer Arbeitsmarkt.' In: Reinhard Kreckel, ed. Soziale Ungleichheiten. Soziale Welt Sonderband no. 2: 347-367.

Reich, Robert. 2010. Nachbeben. Amerika am Wendepunkt. New York: Campus. Original: Aftershock: The Next Economy and America's Future.

Sennett, Richard. 2007. Die Kultur des neuen Kapitalismus. Berlin: Berlin Verlag.

Silver, Beverly J. 2003. Forces of Labor - Workers' Movements and Globalization since 1870. Cambridge: Cambridge University Press.

Sklair, Leslie. 2008. 'Die transnationale Kapitalistenklasse.' In: Berger, Peter A. and Anja, Weiß, eds. Transnationalisierung sozialer Ungleichheit. Wiesbaden: VS-Verlag: 213-240.

Statistisches Bundesamt. ed. 2008. Datenreport 2008. Fakten \& Daten über die Bundesrepublik Deutschland. Wiesbaden.

Statistisches Bundesamt. 2009. Niedrigeinkommen und Erwerbstätigkeit. Begleitmaterial zum Pressegespräch am 19. August 2009 in Frankfurt a. M./ Wiesbaden: 7. 
Streeck, Wolfgang. 2003. 'Gewerkschaften in Westeuropa.' In: Wolfgang Schröder and Bernhard Wessels, eds. Die Gewerkschaften in Politik und Gesellschaft der Bundesrepublik Deutschland. Wiesbaden: VS-Verlag: 86-99.

Streeck, Wolfgang. 2005. Vom „kurzen Traum” zum langen Alptraum? MPIfG Working Paper 05/5, June 2005.

Tait, Vanessa. 2005. Poor workers' unions. Rebuilding labour from below. Cambridge: Southend Press.

Thompson, Edward P. 1963. The Making of the English Working Class. London: 1980: Penguin.

Thompson, Edward P. 1987. Die Entstehung der englischen Arbeiterklasse [1963]. Band 1. Frankfurt a.M.: Suhrkamp (Engl. 1963. The Making of the English Working Class. London 1980: Penguin.).

Van der Pijl, Kees. 1998. Transnational Classes and International Relations. London: Routledge.

Vester, Michael, Christel Teiwes-Kügler and Andrea Lange-Vester. 2007. Die neuen Arbeitnehmer. Zunehmende Kompetenzen - wachsende Unsicherheit. Hamburg: VSA-Verlag.

Wagner, Peter. 1995. Soziologie der Moderne. Freiheit und Disziplin. Frankfurt a.M./ New York: Campus.

Waquant, Loic. 2009. Bestrafen der Armen. Zur neoliberalen Regierung der sozialen Unsicherheit. Leverkusen: Budrich.

Werding, Martin and Marianne Müller. 2007. 'Globalisierung und gesellschaftliche Mitte. Beobachtungen aus ökonomischer Sicht.' In: Herbert-Quandt-Stiftung, ed. Zwischen Erosion und Erneuerung. Die gesellschaftliche Mitte in Deutschland. Ein Lagebericht, Frankfurt a.M.: 103-161.

Windolf, Paul. ed. 2005. Finanzmarktkapitalismus. Analysen zum Wandel von Produktionsregimen. Kölner Zeitschrift für Soziologie und Sozialpsychologie. Sonderheft no. 45. Wiesbaden: VS Verlag: 20-57.

Windolf, Paul. 2008. Eigentümer ohne Risiko. Die Dienstleistungsklasse des FinanzmarktKapitalismus. In: Zeitschrift für Soziologie. no. 6: 515-536.

Wright, Eric Olin. 1985. Wo liegt die Mitte der Mittelklasse? In: Prokla no. 58: 35-62.

WSF Wirtschafts- und Sozialforschung. 2005. Erhebung zur beruflichen und sozialen Lage von Lehrenden in Weiterbildungseinrichtungen. Schlussbericht. Kerpen. 